Studia Anglica Posnaniensia 45/1, 2009

(C) School of English, Adam Mickiewicz University, Poznań, Poland

doi: 10.2478/v10121-009-0010-9

\title{
HEAVEN, HELL AND MIDDANGEARD: THE PRESENTATION OF THE UNIVERSE IN THE OLD ENGLISH GENESIS A
}

\author{
JACEK OLESIEJKO
}

Adam Mickiewicz University, Poznań

\begin{abstract}
Since the times of Antiquity, people have looked up to the sky and developed various conceptions of Heaven and Hell. Already in the ancient Egypt people developed the tripartite conception of universe with earth placed between the Heaven inhabited by gods above and Hell below. The Old English poetic text of Genesis (MS Junius 11; compilation dated to the $10^{\text {th }}$ century) presents the earthly paradise, Hell and Middangeard (or the middle earth). Both Genesis $A$ and $B$ that comprise the poem indeed show a single and consistent descriptions of cosmos. The overt consistency may well seem as interesting as the tradition that the poem draws upon as well as distorts. The universe found in the poem is a fusion of the Christian religious learning as well as Germanic tradition. The idea that marries Heaven, earth and Hell in the poetic sequence of OE Genesis is the concept of hall and anti-hall, city and anti-city. The aim of the following paper is to investigate the modes of this presentation of these parts of the universe by the analysis of the clusters of meaning that are associated with hall and city.
\end{abstract}

Antiquity and the Early Middle Ages saw a number of developments in astronomy and cosmology. Inaccurate as they might appear to the modern science, the contemporaneous cosmological systems were characterised by complexity and a high level of abstraction. In contrast, Anglo-Saxon poetry visualises the universe in a way that is devoid of the intricacy of the Ptolemaic system or the medieval idea of seven Heavens. Jennifer Neville points out to "the absence of an identifiable cosmological system in Old English texts" and observes that "an exception may be the image used to describe the newly constructed world in the Old English Genesis" (1999: 146). The Old English poetic text of Genesis $A^{1}$

1 All the quotations from Genesis are taken from The Junius manuscript (1969). Translations mine own. 
presents a vision of the heavenly paradise, Hell and Middangeard (or the middle earth). The ideas that give expression to the structure of universe in the poem are the concepts of hall and anti-hall, city and anti-city. In the poem, Hell and the burghs of the Middangeard exist as anti-cities, or anti-halls, in relation to the heavenly hall of the universe. The objective of the present study is to investigate the poem's treatment of the idea of universe as a hall.

In Images of community in Old English poetry, Hugh Magenniss points out that "imagery of the good landscape is ... extended to Heaven" and that "Heaven is presented in Old English poetry as a hall, a city and a homeland/home, but Genesis $A$ also draws on the idea of it as a broad kingdom: Heaven is established 'wide and side' by the command of God" (2006: 144). When it comes to the Old English literature, certain modes of presenting Heaven as a city may be chiefly Anglo-Saxon, but the idea itself is not. The analogy between the royal palaces and the heavenly houses of Gods had been drawn since the ancient times. In The early history of Heaven J. Edward Wright observes that in the times of the ancient Israelites "[t]he peoples of the Near East typically imagined that many gods resided in Heaven and functioned in a heavenly assembly ... The chief god - whoever that may be, depending on the tribe, city, or nation - presided over this heavenly assembly" (2000: 72). The most prominent counterpart of this idea in the Christian patristic tradition is $\mathrm{St}$ Augustine of Hippo's concepts of the City of God (the New Jerusalem from the Revelation) and the earthly city. For him, the reality of such a city is grounded by the authority of the Scripture:

The city of God ... is vouched for by those Scriptures whose supremacy over
every product of human genius does not depend on the chance impulses of the
minds of men, but is manifestly due to the guiding power of God's supreme
providence, and exercise sovereign authority over literature of all mankind. Now
in this Scripture we find these words, 'Glorious things have been said of you, City
of God', and in another psalm, 'The Lord is great, and to be highly praised in the
City of God, in his holy mountain, spreading joy over the whole earth'

(Augustine 2003: 429).

The theme of exile offers a universal conception of human life on the earth as estrangement from God; the life in the earthly city is a temporary sojourn of the faithful, to whom the paradise lost will eventually be restored. Augustine's consolation is that "it [the City of God] leads a what we may call a life of captivity in this earthly city as in a foreign land, although it has already received the promise of redemption, and the gift of Spirit as a pledge of it" and that "this heavenly city is ... on pilgrimage in this world" (2003: 877-878). The inclusion of the elements of the earthly landscape in the presentation of Divine abodes both enriches and familiarises the impalpable reality of Heaven that is not con- 
fined to the terrestrial limitations of time and space. At the same time, the human thought desires to invert the analogy in so far as it penetrates the earth for the signs of the reflection of the immaterial extraterrestrial world impressed upon its surface. The presentation of Heaven in Genesis $A$ involves both the transition of the idealised earthly landscape into Heaven and seeking the analogies in the construction of Heaven and earth.

In Poetry, space, landscape: Toward a new theory, Chris Fitter differentiates between the cosmographic and analogical perceptions of space and landscapes in literature. Whereas the cosmographic perception "is alert in landscape to the forces and processes of the world order", the analogical "gratifies the understanding on apprehending phenomena in terms of analogy, polarity, symbol and type" (Fitter 2005: 11). ${ }^{2}$ It seems that the analogical and cosmographic systems of picturing the world order merge in the Old English poem, when it comes to depicting the universe; the text creates the analogy between city and Heaven. Heaven in both parts comprising the sequence of Genesis is thus a city with a communal mead hall ${ }^{3}$ and is contrasted with Hell as well as Middangeard, which appear to be places dominated by wilderness far away from the kingly realm. Genesis A says that "he bið a rice ofer heofenstolas" "God holds the sway over the thrones" (Krapp 1969: 7-8) and wields over "sweglbosmas" 'heavenly strongholds' (1969: 9) that he has established "wide ond side" 'far and wide' (1969: 10) through his might. The basic connotations that the text evokes the heavenly kingdom are those of "gleam" 'joy' (1969: 12) and "dream" 'joy' (1969: 12) as well as "blæd" 'glory' (1969: 14).

The chief two virtues of the heavenly hall are thus the loyalty to God as lord and eternal joy of belonging to the comitatus of this hall. In Genesis A, the divine abode is depicted as an earthly court in which both feasting involving songs and merriment as well as treachery may take place. The angelic hosts that surround God are his retainers that lead a life of service and obedience to their Lord. Satan, who belongs to the angelic comitatus, rebels against God and boasts that he can establish a kingdom in the northern part of the universe. To his dismay, Satan's high expectations are thwarted by God who builds "witehus" 'the house of punishment, Hell' (Krapp 1969: 39) as the place of pain and infliction for the

2 Fitter distinguishes four matrices of perception of landscape. "For primary drives, or matrices of perception, we have identified as perennial are the ecological (the eye to the subsistence and security), the cosmographic (apprehending a conceived world-order, its operating agency and structure), the analogical (perceiving structures of similarity and symbolicity), and the technoptic (identifying in visual experience those codes of appearance it has learned in art" (Fitter 2005: 15).

3 Hugh Magennis points out in Images of community in Old English poetry that "[f]or Augustine and other Christian teachers the idea of Heaven as a city is essentially a spiritual image expressing splendour and community under God" (2006: 41). 
proud and boastful enemy. Hell is an anti-thesis to Heaven in that it involves an inverted idea of the hall. Hell becomes anti-hall, to use the term coined by Kathryn Hume (1974). "Witehus" is a place devoid of joy and festivity and closeness to Lord. The aforementioned nominal compound for Hell is thus depicted as physical construction having the form of a building. It is also a "wraclic ham" 'miserable home' and the place of "hellheafas" 'hellish punishments'. In contrast to the meanings associated with Heaven, it is "dreama leas" 'joyless' (Krapp 1969: 40) and dark. Hell is antithetical to the heavenly kingdom in yet another way; it is depicted as the territory of a hostile tribe. It is indeed an anti-hall. When Satan threatens to establish a competitive kingdom in Heaven, God is presented as a threatening warrior king. He deprives the devils of "sigore and gewealde, dome ond dugoðe" 'victory, power, empire, prosperity' (1969: 55-56) as a lord who invades and exacts loots from a neighbouring tribe.

The text of Genesis $A$ emphasises the contrast between the burgh of Heaven and Hell in terms of architectural design. The ideas of hall and burgh found in Heaven impress upon the reader the ideas of glory and might. The hall of God is "sweglbosm" 'a bright stronghold' (Krapp 1969: 9). The kennings for Hell, on the other hand, highlight the modesty and destitution, as "-hus" and "-ham" are vocabulary attached to buildings inferior in stature to the hall. The hall in the Anglo-Saxon literature is the centre of the civilisation and therefore the further anything is removed from the communal centre the greater impression of wilderness it evokes. When the earth exists in a raw state before being peopled by God, it is described as "idel and unnyt" 'idle and of no use' (1969: 106).

It is thus hardly surprising that Anglo-Saxon poetry depicts both the eternal suffering of the devils and the human existence upon the earth in terms of the exile theme. Wilderness is home to exiles banned from the joys and security of society. The Anglo-Saxons placed the joy of the hall with the lord near at hand and exile, the most severe punishment, at the two opposing ends of the spectrum of social experience. The Old English verse indeed tends to conceptualise the closeness to God in terms of the feasting in the mead hall. God sits at the centre of the universe as "waldend" 'ruler' and the devil's and people's expulsion from Heaven and paradise naturally lend themselves to be mediated by means of the imagery of exile. The relationship between people, angels and God is that of comitatus, a Germanic warrior-group, and requires loyalty to God on the part of angels and humans. The ideal place in the whole Genesis sequence is Heaven with God as a distributor of glory at the centre of the whole universe. In Genesis

4 In "The concept of the hall in Old English poetry", Kathryn Hume claims that "[w] hen chaos and violence take the form of a definite antagonist, a malignant being, its dwelling becomes an anti-hall. This may be as well constructed as a normal hall: the home of the Grendel ménage seems to be" (1974: 68). 
$A$ Satan and his retainers are expelled by God from the heavenly bliss in the same way as Anglo-Saxon lords used to exile their thanes when they proved to be traitors:

$\begin{array}{ll}\begin{array}{l}\text { Sceof pa and scyrede } \\ \text { oferhidig cyn }\end{array} & \begin{array}{l}\text { scyppend ure } \\ \text { engla of heofnum, } \\ \text { wærleas werod. }\end{array} \\ \begin{array}{l}\text { Waldend sende } \\ \text { laðwendne here } \\ \text { on langne sið, }\end{array} \\ \begin{array}{l}\text { beot forborsten, } \\ \text { wlite gewemmed }\end{array} & \text { and forbiged prym, }\end{array}$

[Then our creator expelled and banished the proud hoop of angels from Heaven, the wretched throng. The ruler sent the hostile band of sorrowful spirits on a long journey; their boasting was humbled, their strength and glory diminished].

The fall of Satan is described as "sið" 'journey' (Krapp 1969: 70), which suggests a forced exile from the Lord's retinue. The above-quoted lines repeat the image of the infliction of exile in a way that would suggest an intentional cultural appropriation of the Biblical event into Anglo-Saxon/Germanic ethos. The first sentence has the stronger Biblical resonance, as it uses the terms "scyppend" 'creator' (1969: 67) and "engel" 'angel' (1969: 68), for God and devils respectively. The next sentence, which exists in apposition to the former, draws upon strictly Germanic notions of "Waldend" (1969: 69) as God, which first and foremost applies to a lord and the earthly exercise of power, and "gastas" (1969: 70), which is a more general term for spirits or souls. Also, there is a conception of the banishment from Heaven as a "langne sid" 'long journey' (1969: 70). The appositive sentence thus conceives the event of Satan's fall in terms of exile from comitatus and also gives the idea of Hell as place of exile from Divine presence.

The text of Genesis is consistent in the accentuation of the vivid contrast between the festive joy in Heaven evoking feasts in a mead hall and the tragic vision of solitary and Lordless existence in Hell. When both parts of Genesis describe the fall of rebel angels from heaven, they establish a vivid contrast between exiled angels and those angels who remain with God.

5 In Images of community in Old English poetry, Hugh Magennis observes that "the narratives of the Old English biblical poems concern themselves in some way with the theme of dislocation, which finds its archetypal form in the banishment of Adam and Eve from paradise at the beginning of human history. Journey, wandering, exile are key concerns evident not only in Genesis but also in Exodus, Daniel and - in the theme of humanity's imprisonment in Hell before being released by Christ - Christ and Satan (2006: 149). 
Heo on wrace syððan seomodon swearte, hlude hlihhan, werige wunodon sar and sorge, pystrum bepeahte, pæs pe heo ongunnon pa wæs soð swa ær fægre freopopeawas, peoden his pegnum; duguða mid drihtne, Wæron ba gesome, wuldres eðel

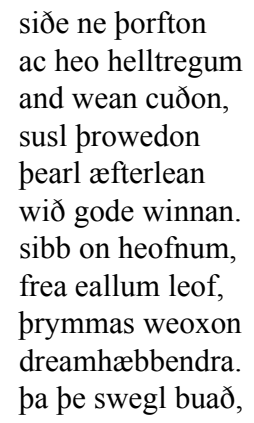

[They were made exiles, these hapless spirits, they had no opportunity to laugh aloud, but were inflicted with hellish flames and learned woe and sorrow. They suffered pain and enveloped in darkness underwent hard retribution, because they struggled against God. Then there was peace in Heaven as before, fair calmness. The lord was dear to all, the Prince to his thanes; the glory increased for the joyous ones who remained with God].

Earlier, Heaven is imagined as the place of "gleam" and "dream" 'joy' (1969: 12), where "engla Jreatas" 'the host of angels' (1969: 13) coexisted with God "on friðe" 'in peace' (1969: 19). Hell prepared by God for the fallen angels is the place of darkness and the quoted passage compliments the description of Hell with a comment on the restoration of "sibb" 'peace' (1969: 78) in Heaven, the good angels being described as obedient retainers.

As Satan is deprived of the light of God following his fall from Heaven, people's expulsion from paradise involves the destitution of resources that Eden had freely offered to them before. The Middangeard is presented in terms of destitution and follows what Chris Fitter calls the "ecological" pattern of presentation that "scans nature as the field of potential satisfaction of requirements for subsistence and security" (2005: 11). God's punishment of Adam is to a large extent the rephrasing of the Scriptural words through the alliterative verse:

$\begin{array}{ll}\begin{array}{ll}\text { Abed each Adame } \\ \text { lifes leohtfruma, }\end{array} & \text { ece drihten, } \\ \text { "pu scealt oðerne } & \text { laðrende: } \\ \text { wynleasran wic, } & \text { and on wræc hweorfan } \\ \text { nacod niedwædla, } & \text { neorxnawanges } \\ \text { dugeðum bedæled; } & \text { pe is gedal witod } \\ \text { lices and sawle. } & \text { Hwæt, pu laðlice } \\ \text { wrohte onstealdest; } & \text { forpon pu winnan scealt } \\ \text { and on eorðan pe } & \text { pine andlifne } \\ \text { selfa geræcan, } & \text { wegan swatig hleor, }\end{array}$


$\begin{array}{ll}\begin{array}{ll}\text { pinne hlaf etan, } \\ \text { oðpæt pe to heortan }\end{array} & \begin{array}{l}\text { penden pu her leofast, } \\ \text { hearde gripeð } \\ \text { adl unliðe }\end{array} \\ \text { pe pu on æple ær } \\ \text { selfa forswulge; } & \text { forpon pu sweltan scealt” }\end{array}$

(Krapp 1969: 925-938)

[The eternal Lord spoke to Adam. The source of life boded him ill. "You shall go to find another homeland, you wretch, and turn to the ways of exile, naked and in constant need, deprived of paradise. Death shall cleave your soul and body. So! You have committed the greatest sin; therefore you shall struggle to win your food by toil on the earth and work in sweat. You will eat your bread as you live here until your sin reaches and gnaws at your heart. Because of the grim illness that you swallowed with the apple, you shall die"].

Chris Fitter points out that "[i]n Anglo-Saxon verse ... landscape reference serves to illustrate religious contemplation of earthly life as doomed mortality and vain achieving" (2005: 174-175). The human transgression in Genesis involves the recognition of the new landscape, Middangeard. ${ }^{6}$ Truly, Middangeard is depicted in Genesis $A$ in the way that Anglo-Saxon elegies lament the transience of life. As devils, God, "ece drihten" 'eternal lord' (Krapp 1969: 925), dispatches Adam on "wræc" 'exile' (1969: 928) that will one day end in death. What is more, "pu sweltan scealt" 'you will die' (1969: 938) that ends God's address to Adam serves as a reminder that human life itself is from now on affected by transience that has begun with the original sin. ${ }^{7}$ The passage foregrounds the idea of alienation of humanity from the place of its origin and destination and its exposition to either indifferent or detrimental natural environment. The idea that now Adam and Eve should "oðerne eðel secean" 'seek another homeland' (1969: 927) serves as a reminder that people have now become strangers to earth. From this time, Adam and Eve have to negotiate their way through the path of hardship and lack of resources. The land has to be conquered and tamed so that it becomes conducive to agricultural activities. Not only does Nature become hostile and poses danger to humanity, but also the Anglo-Saxon rendering of the expulsion from paradise conceives the human existence again in terms of exile.

6 "With the agricultural revolution, the subsequent settling of cultures within defended frontiers, and the concomitant genesis of myths of lost or inaccessible paradise, territorial feeling gains new primacy and demarcates the earth into the contrasting 'domains' of cultural space, wilderness of chaos, and mythic space (Heaven, Hell, the home of the blessed)" (Fitter 2005: 17).

7 The text seems to follow the early Hebrew idea that after death there is no after-life beyond the grave that finds its expression in the Biblical Genesis (Wright 2000: 134) and avoids any evangelical exhortation to seek the post-mortem eternal life with God in heaven, although the AngloSaxon composers of the poem must have been aware of the Christian ideas on salvation. 
As in the Scriptural Genesis, the city of the Middangeard in Genesis A does not occur as the positive centre of human civilisation. In the poem, Babylon, Sodom, and Gomorra appear rather as anti-cities to the heavenly hall. Sodom in the poem appears to be the central anti-city as it exemplifies inhospitality and the poem changes certain details so as to heighten the theme of inhospitality in Sodom. In the Biblical Genesis, when Loth entertains two angels within his household, the citizens of Sodom knock at his door and ask him to lead the two men out of his home. The text of the Bible puts the story in the following way:

\begin{abstract}
But before they lay down, the men of the city, even the men of Sodom, compassed the house round, both old and young, all the people from every quarter: And they called unto Lot, and said unto him, where are the men who came in to thee this night? Bring them out unto us, that we may know them. And Lot went out at the door unto them, and shut the door after him, And said, I pray you, brethren, do not so wickedly. Behold now, I have two daughters which have not known man; let me, I pray you, bring them out unto you, and do ye to them as is good in your eyes: only unto these men do nothing; for therefore came they under the shadow of my roof. And they said, stand back. And they said again, this one fellow came in to sojourn, and he will needs be a judge: now will we deal worse with thee, than with them. And they pressed sore upon the man, even Lot, and came near to break the door. But the men put forth their hand, and pulled Lot into the house to them, and shut to the door
\end{abstract}

(Genesis 19.4-10).

Loth replies that he will give them his two daughters instead and allow them to do with them whatever they wish. He tells them not to do any harm to his guests, as they have found shelter under the roof of his house. The citizens of Sodom do not express any desire to share the entertainment with Loth's guests; they demand Loth should give them away to them. Loth of the Anglo-Saxon poem is a far more threatening figure, as he explicitly expresses his reading to defend his guests by force. The Old English Genesis also elaborates upon Sodomite's response to Loth's exhortation. In the Biblical text, they disapprove of the fact that he patronises them, being a stranger to the city. In the AngloSaxon verse, Loth's foreignness is highlighted through the employment of certain clusters of meaning connected with exile:

$\begin{array}{ll}\text { pis pinceð gerisne } & \text { and riht micel, } \\ \text { pæt pu ðe aferige } & \text { of pisse folcsceare. } \\ \text { pu pas werðeode } & \text { wræccan laste } \\ \text { freonda feasceaft } & \text { feorran gesohtest, } \\ \text { winepearfende. } & \text { Wilt ðu, gif bu most, } \\ \text { wesan usser her } & \text { aldordema, } \\ \text { leodum lareow? } & \end{array}$




\begin{abstract}
[It seems right and appropriate that you leave this land as you have arrived here as an exile deprived of friends; from a distant country you came in need of food. Will you, if you can, be a judge over us and dare to instruct our folk?].
\end{abstract}

In the Old English poem, Loth has suffered exile as friendless and destitute of food and a greater emphasis is put on the fact that he has come from far away. The Old English text thus exemplifies inhospitality as part of the moral failing of the citizens of Sodom. Sodom therefore does not live up to the values that the ideal hall cherishes and is in opposition to Heaven as the ideal hall. It also points to the transience of all human earthly joy by juxtaposing the inhospitality of the citizens of Sodom with the eternal bliss of Heaven.

The image of Heaven as a hall makes for a distinctly Anglo-Saxon presentation of the Christian universe in the Old English Genesis A. The formulaic poetry of the Old English period tended both to christianise the Germanic legacy of the Anglo-Saxons and to germanise the Christian conception of eternal reward for virtuous life. The entire universe is visually constructed as a meadhall. In the Germanic pagan society the hall was the place in which the secular warrior ethos was fostered. The idea of angels as God's retainers in the heavenly hall invokes the Anglo-Saxon political structures and the values of the Old English warrior society are employed to express the idea God's ontological superiority to angels and humanity in terms of political relation between the Lord and his thanes. In this way the Christian ideology adopted the values of the Old English warrior society and revitalised the ethos central to the spirit of their pagan ancestors. Theology imagined the human relations with God in terms of secular power-structures by perceiving reverence to God in terms of a retainer's obedience towards his lord. The idea of Heaven as hall turns out to have structured not only the poetic cosmology of Old English literature but also to have restructured the moral universe of the recently christianised Anglo-Saxon imagination.

\title{
REFERENCES
}

\section{PRIMARY SOURCES}

\author{
Augustine \\ 2003 The city of God. (Translated by Henry Bettenson.) London: Penguin Books. \\ The Old Testament \\ 1996 The Old Testament. King James' version. Everyman's Library: London \\ Krapp, Philip (ed.) \\ 1969 The Junius manuscript. New York: Columbia University Press.
}




\section{SECONDARY SOURCES}

Battles, Paul

2002 "Genesis A and the Anglo-Saxon "migration myth", Anglo-Saxon England 29: 43-66.

Fitter, Chris

2005 Poetry, space, landscape. Towards a new theory. Cambridge: Cambridge University Press.

Hume, Kathryn

1974 "The concept of the hall in Old English poetry", Anglo-Saxon England 3: 63-74.

Magennis, Hugh

2006 Images of community in Old English poetry. Cambridge: Cambridge University Press. Neville, Jeniffer

1999 Representation of the natural world in Old English poetry. Cambridge: Cambridge University Press.

Wright, J. Edward

2000 The early history of Heaven. Oxford: Oxford University Press. 